\title{
Climate influences on Vaal River flow
}

\author{
Mark R Jury ${ }^{1,2 *}$ \\ 'Physics Dept, University of Puerto Rico Mayagüez, PR 00681, Puerto Rico \\ ${ }^{2}$ University of Zululand, KwaDlangezwa, 3886, South Africa
}

\begin{abstract}
A study of climatic influences on Vaal River discharge, near Johannesburg, South Africa, finds that peak summer flows in the period 1979-2014 coincide with ocean-atmosphere interaction in the east Atlantic. The analysis has three parts: interannual influences by correlation of summer discharge with climate fields, atmosphere and ocean composites of 14 peak flow months, and a case study flood in January 2010 and its regional scale forcing. Inter-annual links are established with low pressure over the east Atlantic and an eastward equatorial ocean current and suppressed upwelling in the northern Benguela. During the January 2010 flood in the Vaal River, flow increased to $2801 \mathrm{~m}^{3} / \mathrm{s}$. There was a low salinity plume and warm sea temperatures off Angola $>29^{\circ} \mathrm{C}$. A terrestrial vegetation fraction $>0.6$ and corresponding latent heat fluxes enriched NW-cloud bands over the Vaal River catchment, during the flood case study of January 2010. Comparison of (Pacific) Southern Oscillation and east Atlantic influence on Vaal River discharge reveals the former drives evaporative losses while the latter provides an advance warning of flow variability
\end{abstract}

Keywords: Vaal River, hydro-meteorology, climate influence

\section{INTRODUCTION}

The Vaal River flows west near Johannesburg, South Africa (Appendix A1), eventually joining the Orange River and draining into the Atlantic Ocean. Typical summer (Jan-Mar) discharge is $\sim 300 \mathrm{~m}^{3} / \mathrm{s}$; supporting urban services, industry and agricultural production within the catchment of $\sim$ USD100 billion/yr, via storage dams such as the Vaal $\left(2200\right.$ million $\left.\mathrm{m}^{3}\right)$ and Bloemhof $\left(1200\right.$ million $\left.\mathrm{m}^{3}\right)$. Dry season base flow is maintained by transfers from the south (ORASECOM, 2015). The climate is sub-tropical dry savannah with mean annual evaporation at $\sim 1300 \mathrm{~mm}$, far exceeding rainfall of $\sim 600 \mathrm{~mm}$. Seasonal river discharges and rainfall fluctuate from year to year $(\mathrm{CV}=0.3)$, a constraint to production and resource development (Tadross et al., 2005).

Variations in the flow of Africa's larger rivers, such as the Congo, have been linked to east Atlantic sea surface temperatures (SST) and continental-scale climate anomalies (Hirst and Hastenrath, 1983a; Jury and Engert, 1999; Jury et al., 2000; Camberlin et al., 2001; Rouault et al., 2003; Todd and Washington, 2004). In contrast, the Kalahari Desert that spreads east from Namibia sees little rainfall due to subsident equatorward winds over the cold Benguela Current. Occasionally NW-cloud bands form with a cut-off low (Taljaard, 1985) and bring much-needed rains by linking moist air flows from the Congo basin (Jury, 2010) and east Atlantic Ocean.

Two types of tropical Atlantic variability have been noted: a north-south dipole (Servain et al., 1982; Chang et al., 1997) and an equatorial mode (Zebiak, 1993), both with some degree of external modulation (Enfield and Mayer, 1997; Chang et al., 2000; Saravanan and Chang, 2000; Sutton et al., 2000). The Atlantic equatorial mode is a zonal see-saw similar to the Pacific Southern Oscillation (Hirst and Hastenrath, 1983b; Philander, 1986; Carton and Huang, 1994; Latif and Grötzner, 2000), but much smaller as dictated by the basin size, lower SST and weaker atmospheric convection. The tropical Atlantic has strong easterly trade winds that generate an equatorial

\footnotetext{
* To whom all correspondence should be addressed:

e-mail:mark.jury@upr.edu

Received: 24 November 2014; accepted in revised form 8 March 2016
}

cold tongue and a steeply sloping thermocline. When the trade winds weaken, the zonal sea slope relaxes. A deepening of the thermocline by Kelvin wave propagation results in eastward equatorial currents that push warm water toward Africa, with consequences as outlined below.

The objective of this paper is to understand how the regional climate modulates year-to-year changes in summertime Vaal River flow since 1979. Then the flood of January 2010 is studied to uncover links with NW-cloud bands, as in Muller et al. (2007). Results are presented for the analysis of monthly river discharge and regression onto climate fields, composite investigation of a group of 14 high-flow months, and influences at regional scale using reanalysis and satellite data.

\section{DATA AND METHODS}

Vaal River flow monthly data was obtained via South Africa's Department of Water and Sanitation hydrology service website for the gauge at Pilgrim/Orkney $\left(27^{\circ} \mathrm{S}, 26.7^{\circ} \mathrm{E}\right.$, Fig 1a) in the period 1979-2014. Above the gauge, the catchment is $\sim 410^{4} \mathrm{~km}^{2}$ and the difference between transfers and offtake is $+2.3 \mathrm{~m}^{3} / \mathrm{s}$ (ORASECOM, 2015). Its temporal oscillations are studied by wavelet spectra (Torrence and Compo, 1998). Potential evaporation rates are based on in-situ S-pan measurements near the river gauge merged with estimated sensible heat flux. Hydrological records are supported with catchment-averaged $\left(26-28^{\circ} \mathrm{S}, 25-29.5^{\circ} \mathrm{E}\right)$ monthly GPCC rain-gauge observations (Schneider et al., 2013) interpolated by satellite to $50 \mathrm{~km}$ grid. Land surface temperature is measured using de-clouded MODIS satellite infrared data (Huete et al., 2002).

To quantify climate influences on Vaal River discharge in Jan-Feb, point-to-field correlations were computed. A lead time of 1-month (Dec-Jan) was determined by lag-correlation with catchment rainfall $(r=0.64)$. Reference fields were drawn from MERRA reanalysis (Rienecker et al., 2011) surface temperature, sea level pressure (SLP), latent and sensible heat flux. Vaal River summer discharge was correlated with regional GPCP satellitegauge merged rainfall, GRACE satellite soil moisture (Tapley et al., 2002) and NASA satellite vegetation fraction (Tucker et al., 2005). With 34 degrees of freedom, $90 \%$ confidence is achieved for 
Pearson product-moment $r>|0.30|$, following methods of Potter et al. (2004) and Glad (2010). Exploratory mapping and cluster analysis revealed the main zone of climate influence to be $10^{\circ} \mathrm{W}-40^{\circ} \mathrm{E}$, $10^{\circ} \mathrm{N}-35^{\circ} \mathrm{S}$, eliminating ocean areas south and east of Africa. All analyses are linear detrended. Correlations imply multivariate climate influences and not causality by an individual mechanism.

Regional atmosphere and ocean circulation anomalies were averaged for 14 peak discharge months, determined by ranking: Jan '80, Feb '81, Feb '88, Jan '89, Jan-Feb '96, Apr '97, Dec '97, Jan '00, Nov '00, Feb '06, Dec '09, Dec '11 and Feb '14 (chronologically). These months have a mean Southern Oscillation Index value of 0.4 and thus fall in the neutral range. The meteorological scenario of a flood on 23-26 January 2010 was studied via daily satellite rainfall (Joyce et al., 2004), NCEP (Kalnay et al., 1996) and MERRA reanalysis winds, NOAA satellite SST (Reynolds et al., 2007) and Hycom-GODAS ocean reanalysis (Chassignet et al., 2009) surface salinity and upper layer currents. That season (2010) had a high incidence of NW-cloud bands according to a cluster analysis of rainfall, yet the Southern Oscillation Index was -1.1. A focus on summer eliminates the seasonal cycle and minimizes the effects of water resource engineering, so enabling the Vaal River discharge to provide a basis for study of natural climate influences.

\section{RESULTS}

\section{Vaal River discharge}

Figure 1a-c introduces the Vaal River catchment, falling from the Drakensberg Escarpment near Swaziland $\left(29.5^{\circ} \mathrm{E}\right.$, $1550 \mathrm{~m}$ amsl) with a zonal gradient of $\sim 1 \mathrm{~m} / \mathrm{km}$. The changing elevation produces a cool-east to warm-west temperature
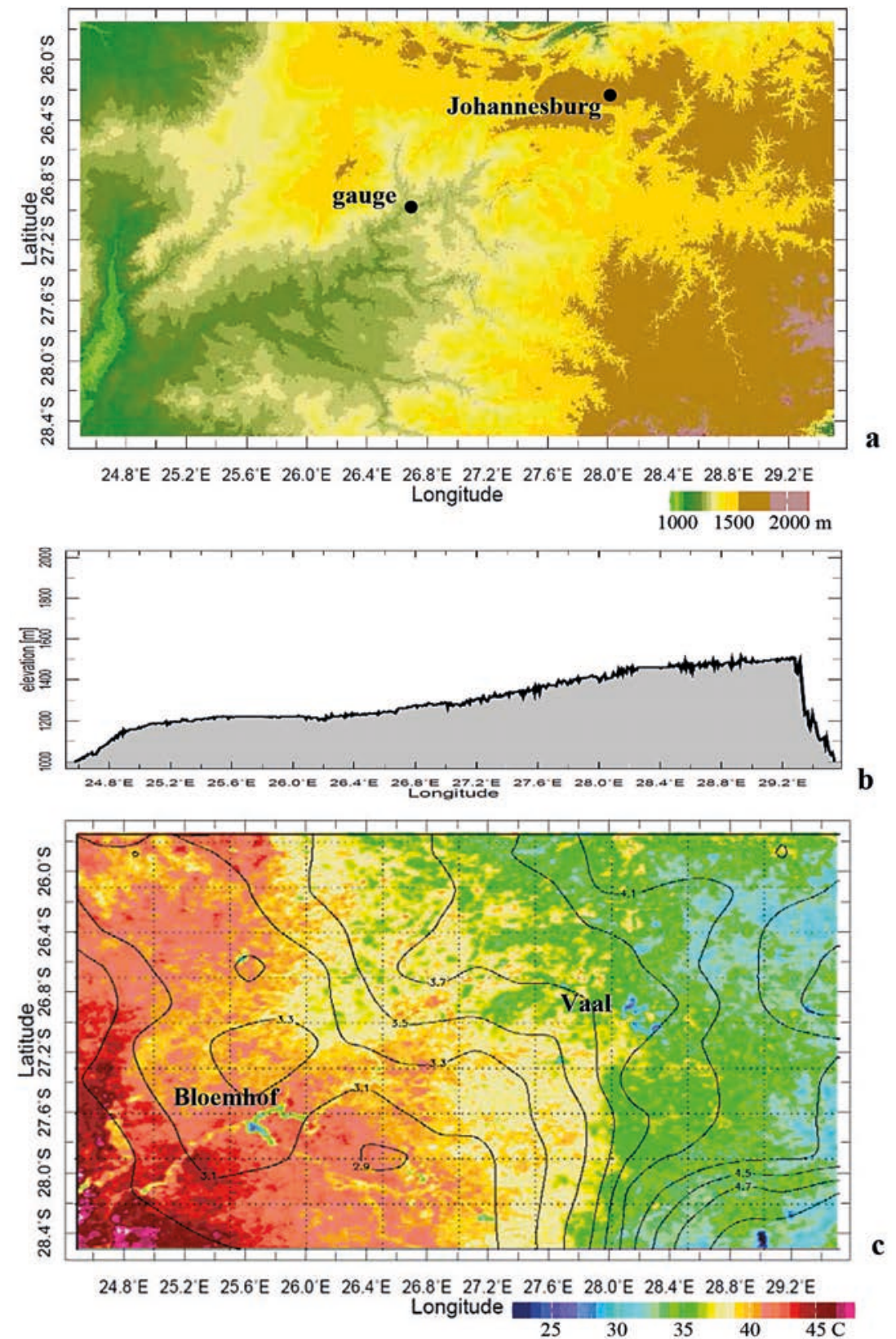

Figure 1

Vaal River study area: (a) topography, (b) zonal slope, (c) satellite infrared day-time land surface temperature Dec-Jan average over 2000-2012 and similarly averaged rainfall (contour, $\mathrm{mm} /$ day). Key place names are given, and the discharge gauge is shown. 
gradient (Fig. 1c) that mirrors mean summer rainfall: $4.5 \mathrm{~mm} /$ day in the east $\left(29.5^{\circ} \mathrm{E}\right)$ to $2.8 \mathrm{~mm} /$ day in the west $\left(25^{\circ} \mathrm{E}\right)$. The mean Dec-Jan daytime land surface temperature is $38^{\circ} \mathrm{C}$ near the gauge, and potential evaporation is high.

Vaal River discharge at $27^{\circ} \mathrm{S}, 26.7^{\circ} \mathrm{E}$ from $1979-2014$ (Fig 2a) has a 2\% up-trend due to imported base flows. Summer (Jan-Mar) peaks follow catchment runoff with spikes $>300 \mathrm{~m}^{3} / \mathrm{s}$ half the time. Seasonal discharge was limited in
1982-86, 1990-95, 2002-05, 2007-08, 2012-13. Despite the dry spells, there has been an overall recovery of discharge that started with the 1996 flood. The wavelet spectra (Fig 2b) illustrates a prevailing $4-5 \mathrm{yr}$ oscillation since 1990 , with secondary 2- and 10-yr rhythms in the 1990s. The mean annual cycle (Fig. 2c) shows that catchment rainfall picks up in OctNov, but runoff is delayed by high potential evaporation, so discharges rise in December and peak by Feburary. Here our
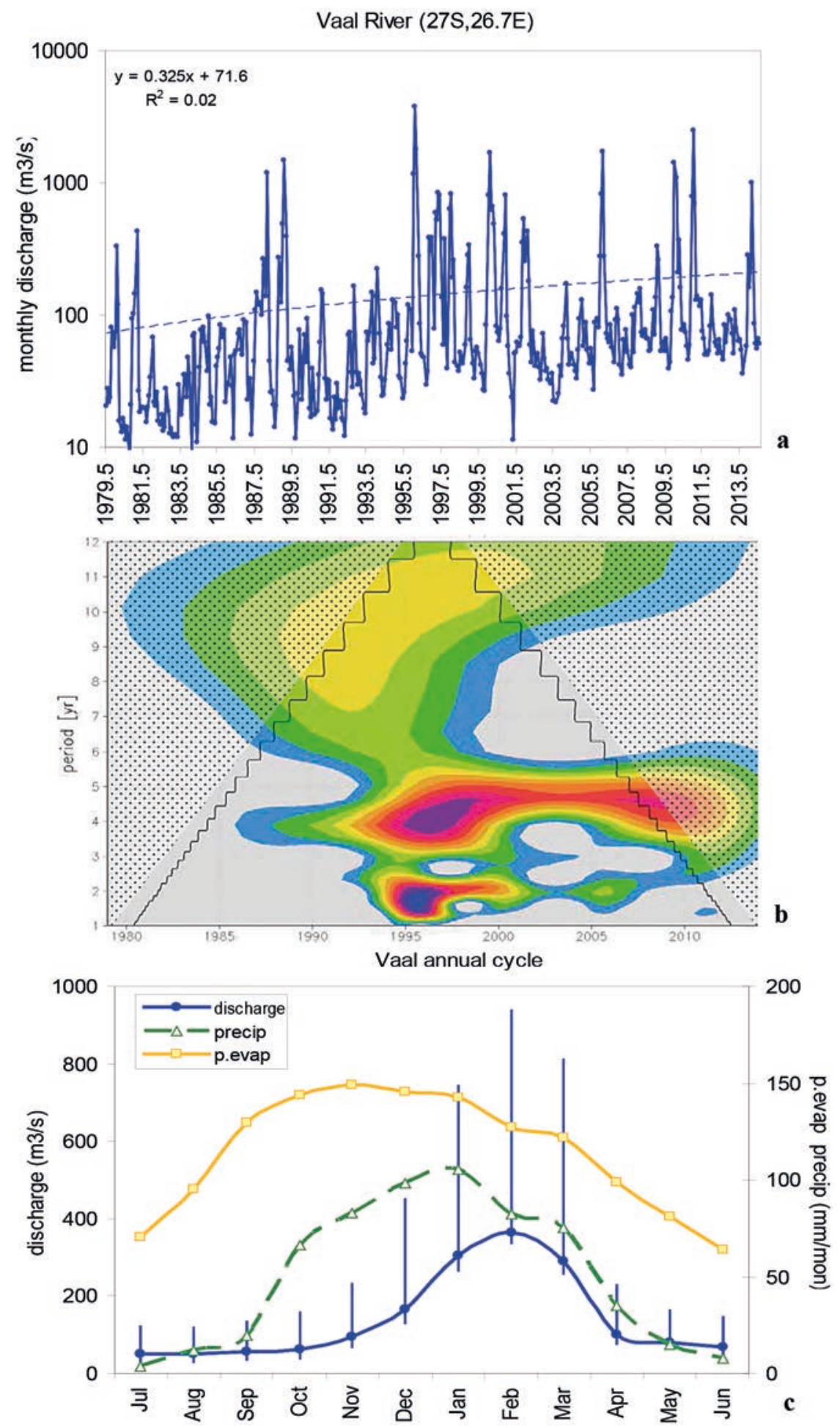

Figure 2

(a) Discharge of the Vaal River and its trend. (b) Wavelet spectra of smoothed Vaal discharge, with power shaded $>90 \%$ confidence and cone of validity. (c) Mean annual cycle of discharge and its upper/lower quintiles, catchment rainfall and potential evaporation. 
interest is regional controls on rainfall, so the focus is DecJan influence on Jan-Feb discharge.

\section{Hydro-climate influence}

Fluctuations of African river flow have previously been related to the (Pacific) Southern Oscillation and Indian Ocean SST
(Amasekara et al., 1997; Kruger, 1999; Dettinger and Diaz, 2000; Alemaw and Chaoka, 2006), yet the Vaal discharge will show a closer relationship with the east Atlantic. Hence we want to uncover and explain those links at both seasonal and event time scales.

The correlation maps with respect to Jan-Feb Vaal discharge are given in Fig. 3a-f. The Dec-Jan GPCP rainfall
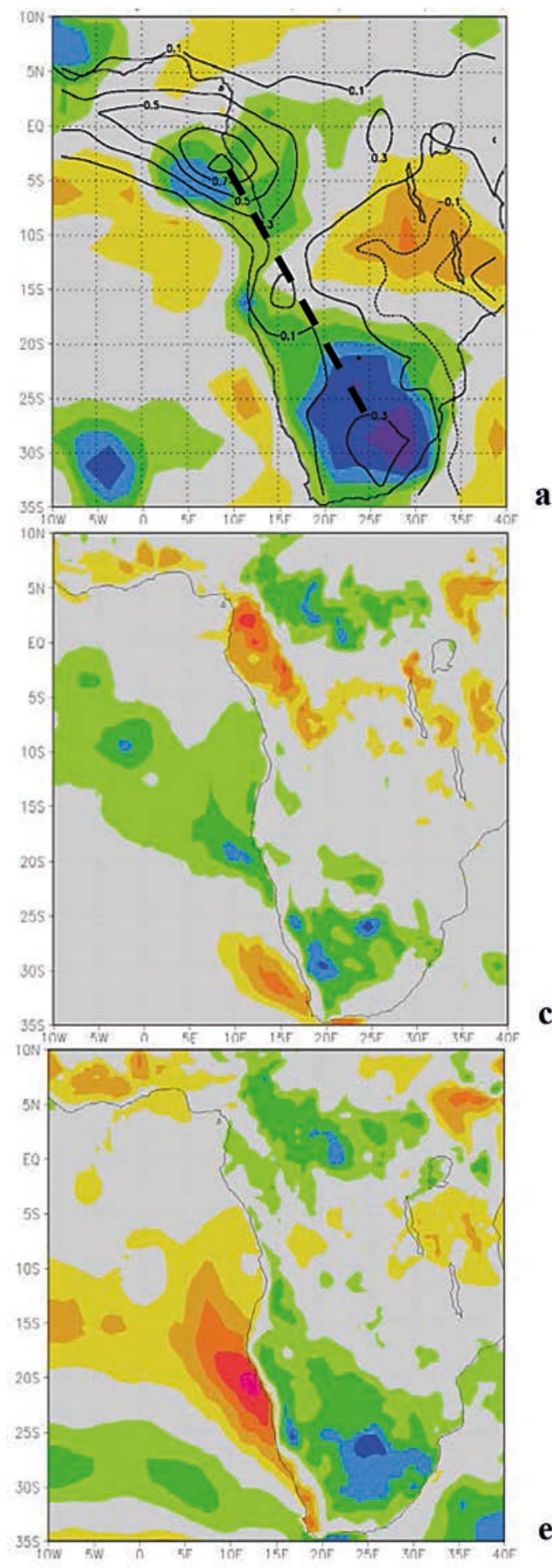

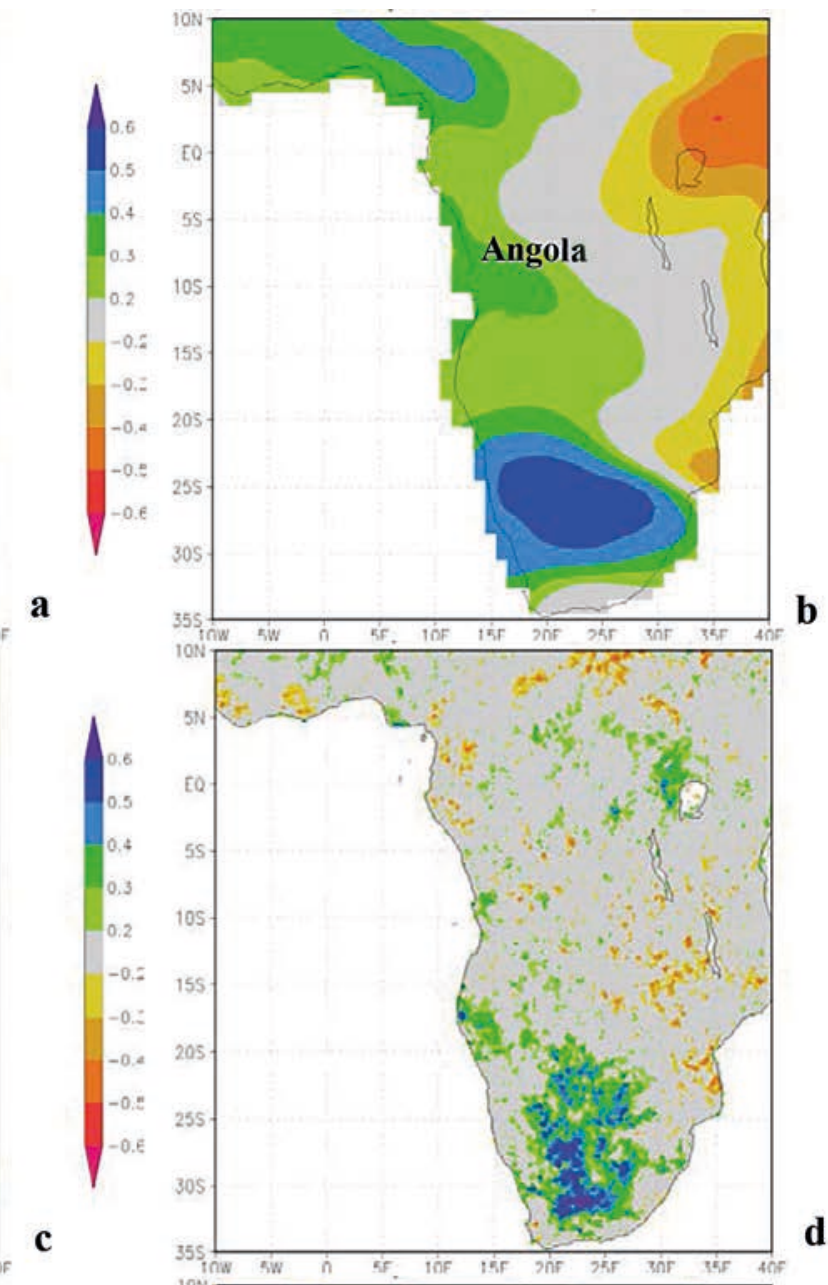

d

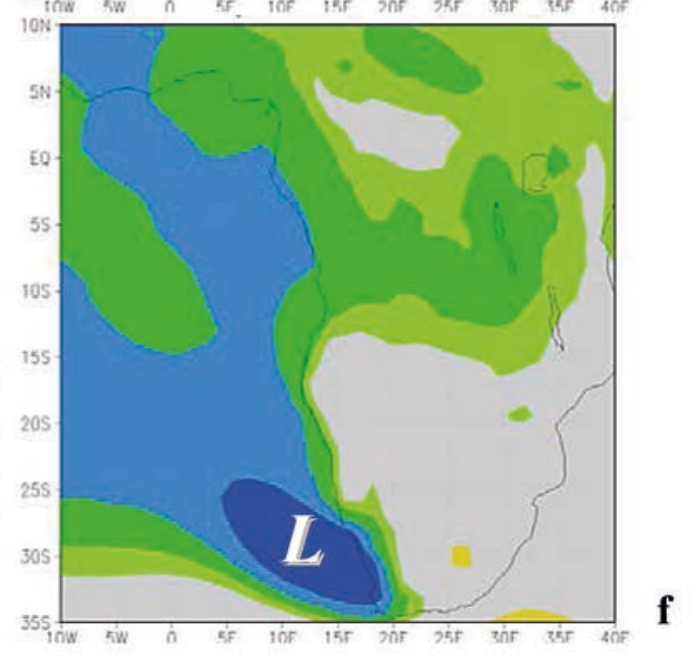

Figure 3

Correlation of Vaal River Jan-Feb discharge with detrended Dec-Jan: (a) rainfall, (b) soil moisture, (c) latent heat flux, (d) satellite vegetation index, e) surface temperature, (f) sea level pressure. All over 1979-2014 except (b) 2002+. Color bar refers to both left and right sides, blue is high in top panels. Contours in (a) are cluster-3 rain amplitude; dashed line is NW axis of influence. 
is locally correlated as anticipated. Yet there is a NW-axis (Fig. 3a), that extends past Angola. Supporting that pattern is soil moisture which has the local correlation but also a positive zone all along the African west coast from Angola to Nigeria (Fig. 3b). Along the African east coast from Mozambique to Kenya, soil moisture correlations with Vaal discharge are negative. Together these form an E-W dipole pattern. The MERRA latent heat flux and satellite vegetation index correlations are also locally positive with a NW-axis that extends past Angola. $\mathrm{NW}$-aligned features are noted over the Benguela upwelling zone and across central and east Africa (Fig. 3c,d). Temperature correlation patterns are locally negative (Fig. 3e) as expected. The Benguela Current shows marked warming particularly off Namibia which coincides with lower pressure: the South Atlantic anticyclone weakens during periods of high Vaal River discharge. Negative correlations stretch across Africa north of the Zambezi Valley in the Dec-Jan season (Fig 3f). The low pressure signal extends northward over the entire east Atlantic up to $30^{\circ} \mathrm{N}$ (not shown).

Composite vector wind anomalies averaged over 14 peak discharge months are illustrated in Fig. 4a,b. A key feature is the low-level cyclonic circulation over Botswana that induces onshore flow over Angola and poleward flow over the Zambezi Valley. The tropical westerly circulation helps explain the soil moisture dipole, with upslope flow over the Atlantic coast favouring convection, and downslope flow over the Indian coast hindering it. In the upper atmosphere, there is a trough over the South Atlantic that spins down the surface anticyclone and re-directs tropical easterlies along a poleward path over southern Africa, in conjuction with a small anticyclone over Mozambique.

Composite ocean currents, sea temperatures and salinity
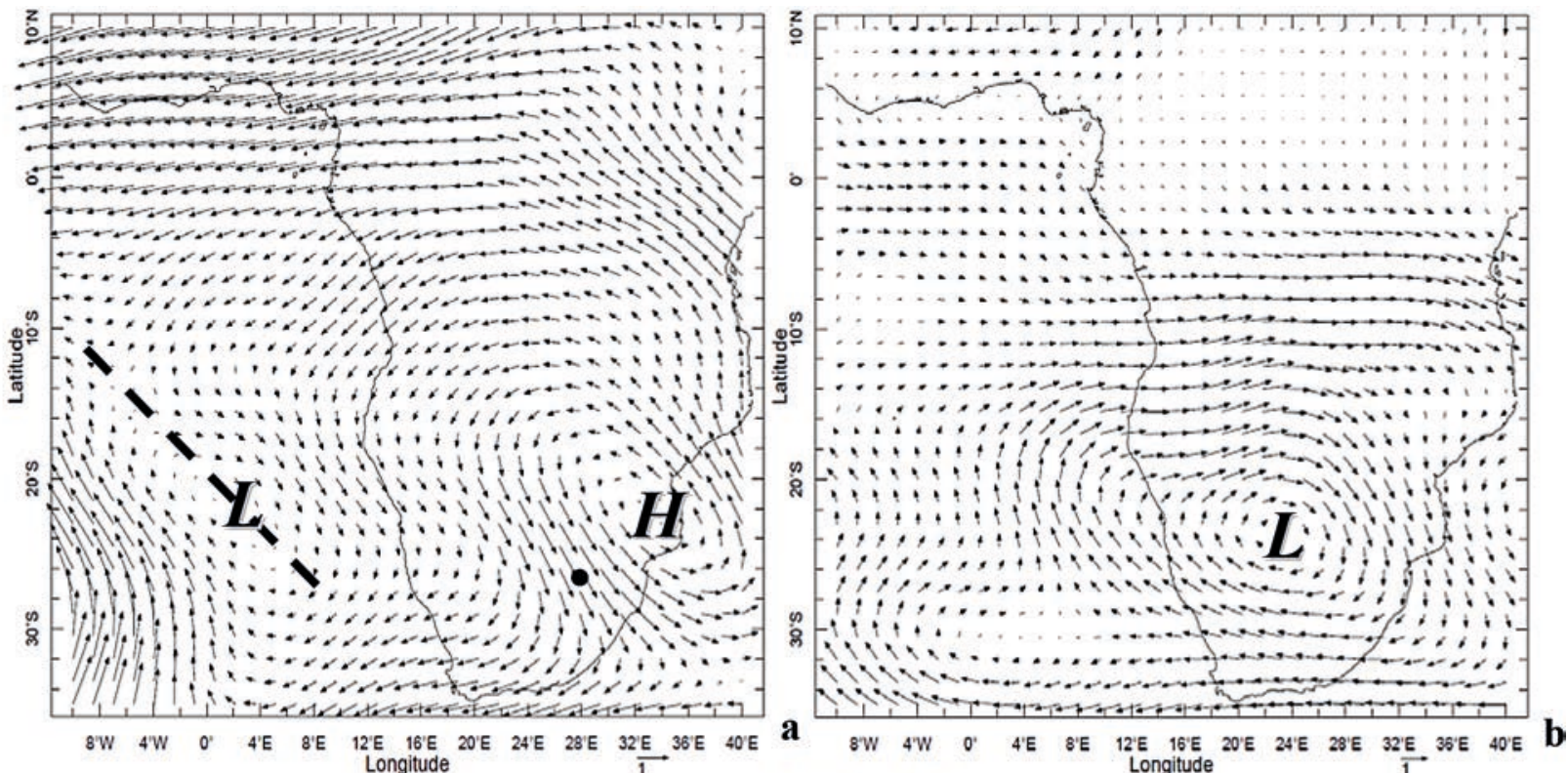

$\begin{array}{lllllll}8^{\prime} W & 4^{\prime} W & O^{\prime} & 4^{\prime} \mathrm{E} & 8^{\prime} \mathrm{E} & 12^{\prime} \mathrm{E} \text { 16'E } \\ \text { Longitude } & 20^{\prime} \mathrm{E} & 24^{\prime} \mathrm{E} & 28^{\prime} \mathrm{E} & 32^{\prime} \mathrm{E} & 36^{\prime} \mathrm{E} & 40^{\prime} \mathrm{E}\end{array}$

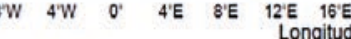
b

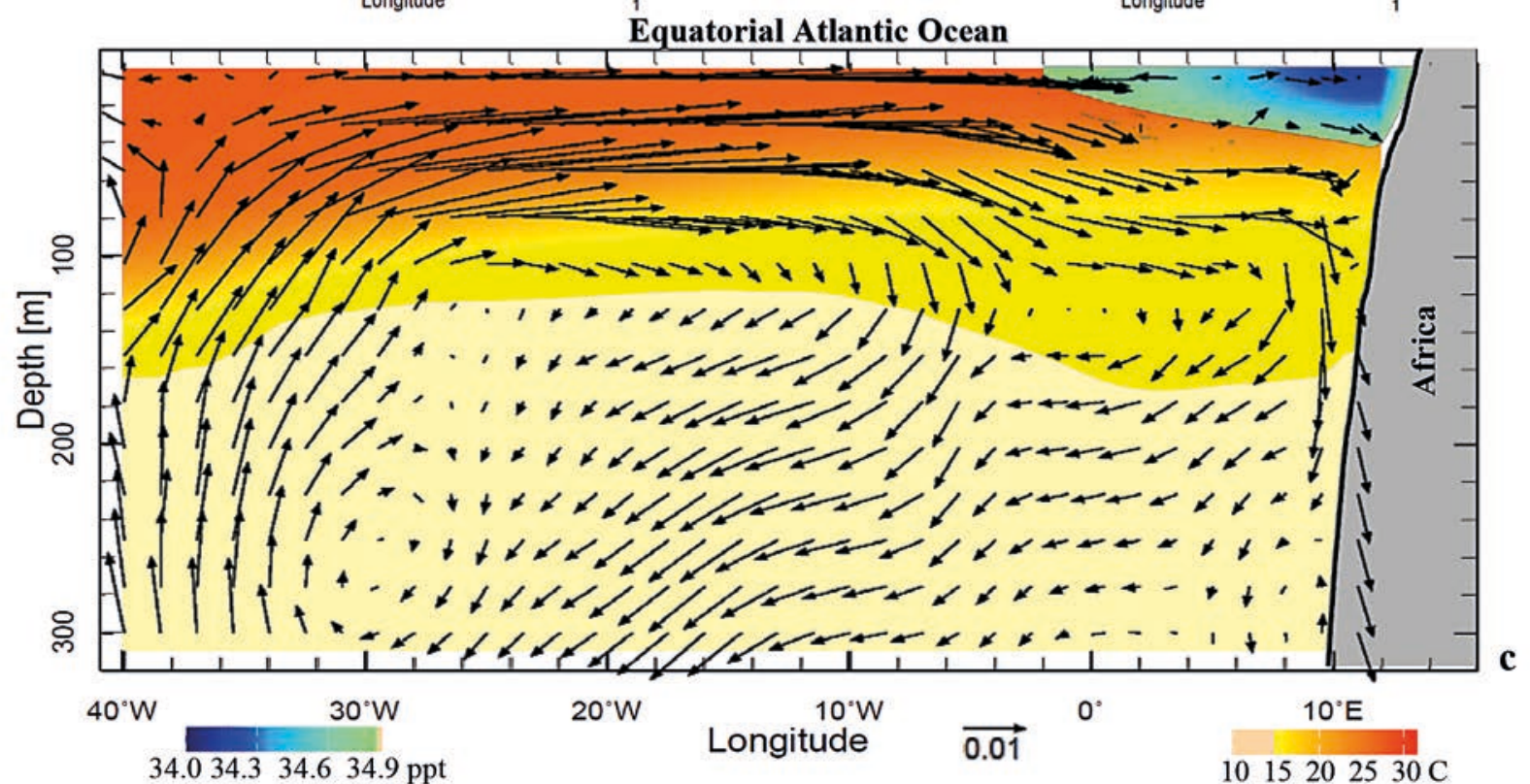

Figure 4

Composite anomalies of (a) $200 \mathrm{hPa}$ and (b) $850 \mathrm{hPa}$ winds in 14 peak flow months 1979-2014. Dot is river gauge. (c) Composite U W current anomaly vectors, sea temperature (shaded orange $>15^{\circ} \mathrm{CC}$ ) and salinity (shaded blue $<34.9 \mathrm{ppt}$ ) in the equatorial Atlantic $\left( \pm 5^{\circ} \mathrm{C}\right.$ ) during the same composite months, illustrating a zonal overturning circulation. 
are analysed for the same 14 peak discharge months (Fig. 4c). The depth section covers the entire equatorial Atlantic and illustrates a reversal of the zonal overturning ocean circulation, with rising motion near Brazil and sinking motion off Africa. Equatorial current anomalies are eastward toward Africa, particularly in the 1-100 $\mathrm{m}$ warm layer. This ocean circulation is driven by a weakening of the subtropical anticyclones in both the South and North Atlantic, and consequent relaxation of trade winds and zonal sea slope. This usually happens after austral winter (Keenlyside and Latif, 2007), so its appearance in summer is exceptional.

\section{The 2010 flood in context}

The Vaal River flow spikes in most summers, one of which was January 2010. Considering daily data, there was a rise through January to $2802 \mathrm{~m}^{3} / \mathrm{s}$ by month end. The steepest rise was in the period 23-26 January (Fig. 5a). The satellite rainfall averaged over those days has NW-banded features (Fig. 5b) extending from the east Atlantic, across Angola into the Zambezi Valley.
Further south there was a circular feature with convective elements on the poleward flank. $850 \mathrm{hPa}$ winds on 25 January (Fig. 5b) illustrate how tropical easterlies from the Congo basin were re-directed to southern Africa. There was a cyclonic rotor that accelerated poleward flow over the Vaal catchment. Equatorial ocean currents were eastward and curved poleward off Angola (Fig. 5c) and the vegetation fraction was $>0.6$ across southern Africa due to persistent rains. Diurnal transpiration $\left(>300 \mathrm{~W} / \mathrm{m}^{2}\right)$ stimulated evening thunderstorms over the Vaal catchment.

Marine conditions during the 2010 flood peak are described in Fig. 6a,b. In the source region of the NW-cloud band, SST were above $29^{\circ} \mathrm{C}$, a temperature capable of sustaining deep convection. There was a large plume of fresh water $(<33 \mathrm{ppt})$ extending southward from the Gulf of Guinea (Fig. 6b), owing to high discharge from the Congo River in the preceeding season. The fresh water is buoyant, so surface heat builds in a shallow layer. SST anomalies were $1-2^{\circ} \mathrm{C}$ above normal in the tropical Southeast Atlantic Ocean off Angola.
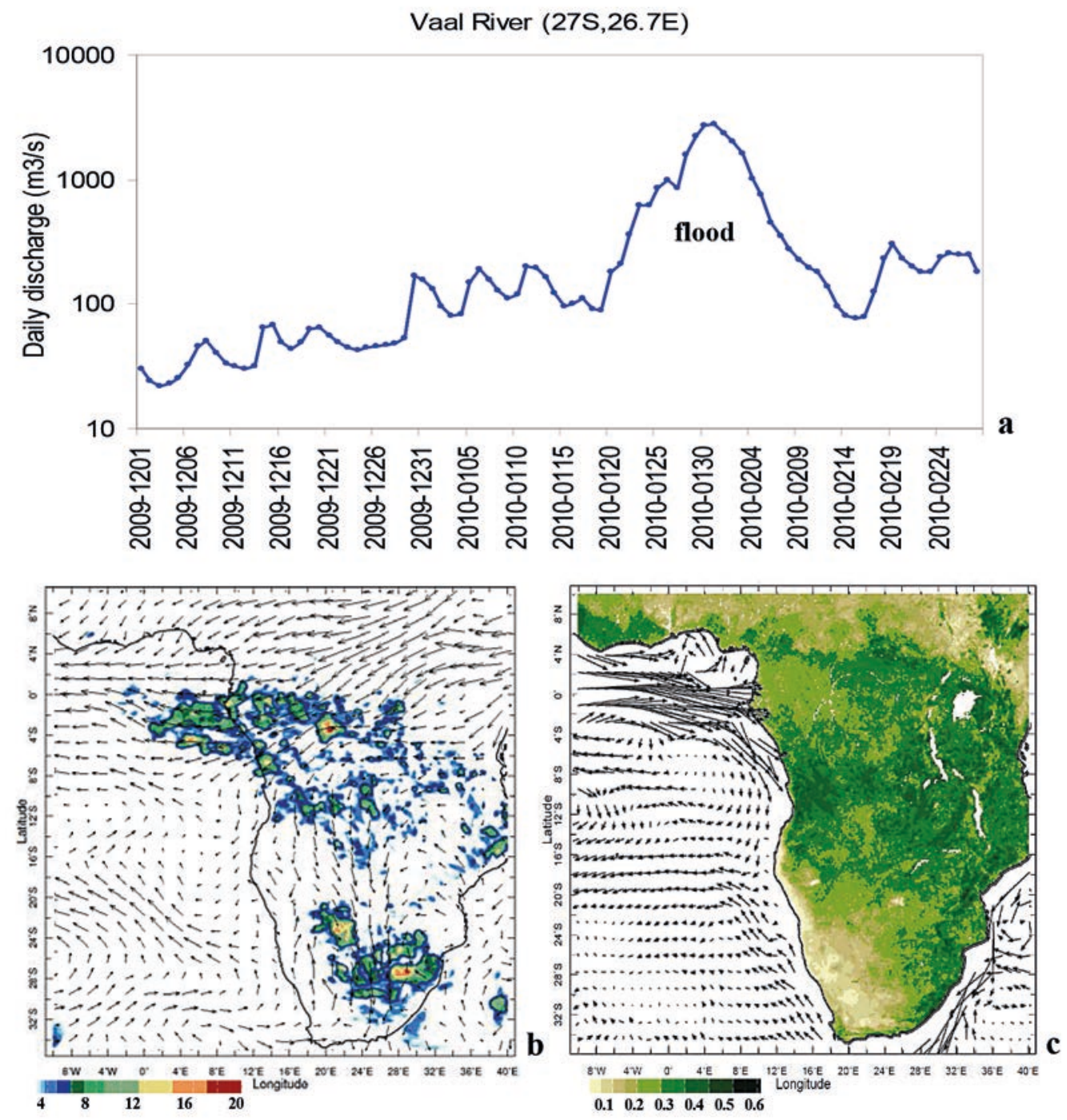

Figure 5

January 2010 flood event, (a) Vaal River daily hydrograph, (b) satellite rain rate ( $\mathrm{mm} / \mathrm{hr}$ ) and $850 \mathrm{hPa}$ winds (largest $10 \mathrm{~m} / \mathrm{s})$ averaged $23-26 \mathrm{January}$; (c) satellite vegetation fraction and 1-50 m ocean currents (largest $0.5 \mathrm{~m} / \mathrm{s}$ ) averaged 15-30 January. 

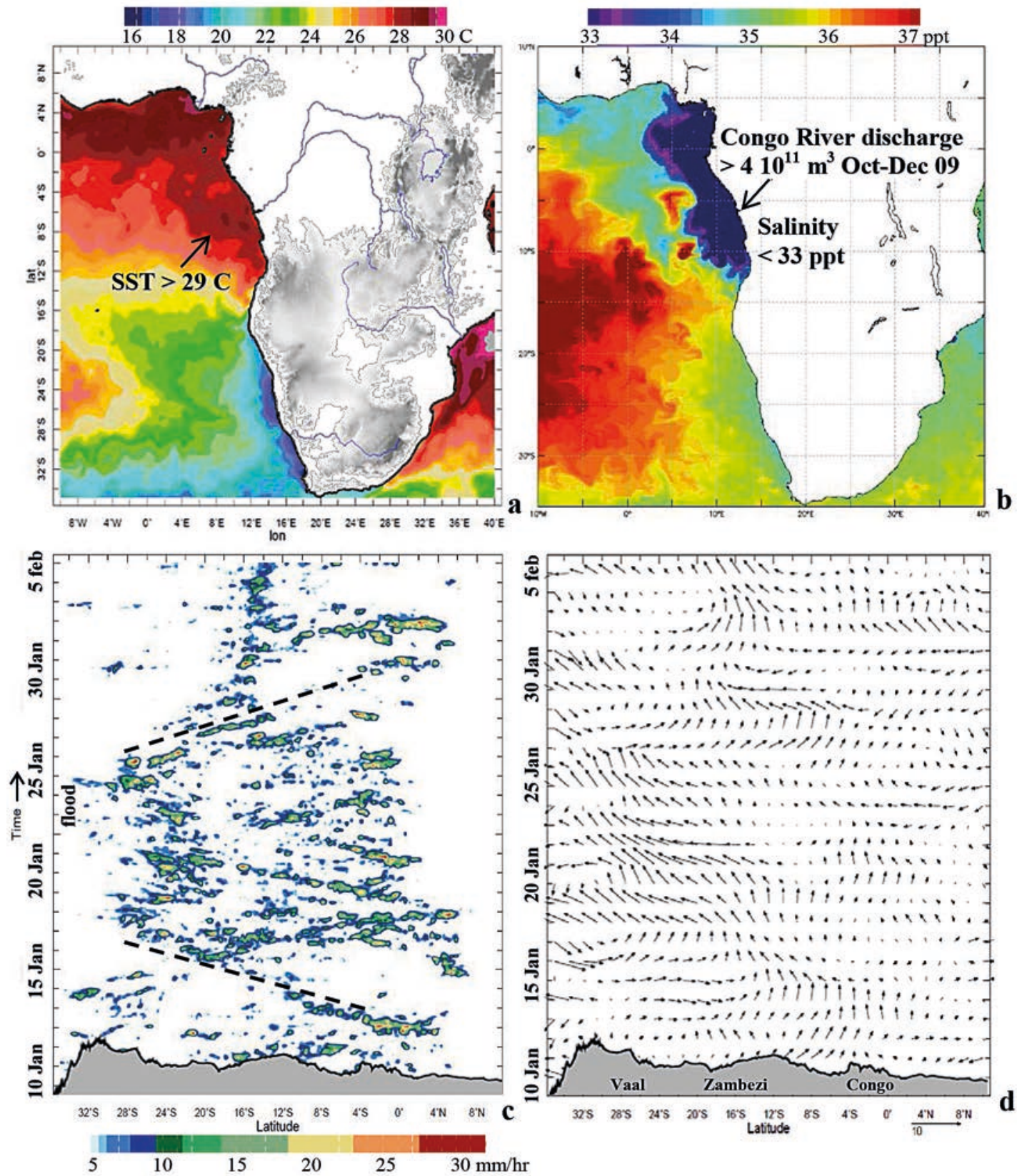

Figure 6

(a) Sea surface temperature, (b) sea surface salinity averaged 23-26 January 2010. Elevation $>1000$ m shaded with major rivers in (a). Hovmoller plots (south-to-north) along $27 \mathrm{E}$ from $10 \mathrm{Jan}-5 \mathrm{Feb} 2010$ of (c) 3-h satellite rainfall, (d) $700 \mathrm{hPa}$ meridional wind combined with $500 \mathrm{hPa}$ vertical motion. Schematic topography and river basins given; dashed lines show advance and retreat of the ITCZ in (c).

To place the floods in context, a latitudinal hovmoller analysis is made (Fig. 6c,d). This perpective is unusual: instead of zonal convective waves, the focus is on the advance and retreat of the ITCZ. There were multiple, sustained wavelike features that identify progressive southward movement $(500 \mathrm{~km} /$ day) of equatorial convection from the Congo basin to southern Africa in mid-January 2010. Similarly, the hovmoller plot of meridional wind and uplift reveals a gradual poleward shift of northerly flow: from mid-January over the Zambezi, to the Vaal catchment by the flood event. This was followed by a clear retreat of convection back to the Zambezi, with thunderstorm clusters pushed along by southerly winds in early February.
According to Meteosat IR imagery (European Satellite Agency, 2015), a convective vortex over the Kalahari on 24 January 2010 presented circular cloud bands. As this system drifted southeastward, cloud-top temperatures reached $-90^{\circ} \mathrm{C}$ over the Vaal catchment on 26 January 2010 and rainfall $>100 \mathrm{~mm} /$ day was reported.

The atmospheric circulation as a north-south height section during the flood (23-26 Jan) is given in Fig 7a. There is no clear Hadley overturning; rather poleward flow was deep $(900-300 \mathrm{mb})$ and broad $\left(30^{\circ} \mathrm{S}-10^{\circ} \mathrm{N}\right)$. Easterlies were observed over the Congo and Zambezi. The southern hemisphere subtropical jet stream was present $(20 \mathrm{~m} / \mathrm{s})$ south of $30^{\circ} \mathrm{S}$. Together these produced anticyclonic divergence favourable to flooding 
in the catchment. The same height section, but east-west, is given in Fig. 7b. A NW-trough was evident; incoming westerlies reached a maximum at $200 \mathrm{hPa}$ over the east Atlantic $\left(5-10^{\circ} \mathrm{E}\right)$. The trough-induced northerly flow penetrated toward the Vaal catchment, and converged and lifted with help from an upper ridge east of southern Africa (i.e. $200 \mathrm{hPa}+\mathrm{V}$ at $35-40^{\circ} \mathrm{E}$ ).

\section{DISCUSSION}

\section{Atlantic influence}

Vaal River discharge was earlier related to Atlantic sea-level pressure (Fig. 3f), a signal that is part of a secondary mode of global climate variability, after the Pacific Southern Oscillation zonal dipole. It refers to changes of pressure over the east Atlantic involving both North and South Atlantic anticyclones. When these anticyclones weaken and the intervening trade winds relax, the zonal sea slope $\partial \eta / \partial x$ diminishes resulting in a reversal in the overturning circulation (Rouault et al., 2003) seen in the equatorial Atlantic (Fig. 4c).

Formuating a SLP index over the east Atlantic: $30^{\circ} \mathrm{S}-35^{\circ} \mathrm{N}$, $40^{\circ} \mathrm{W}-20^{\circ} \mathrm{E}$ and calculating lag correlations with respect to Dec-Feb Vaal River flow, the graph (Fig. 8a) reveals an advance warning capability. Negative correlations become significant at -4 months and continue to +1 month, reaching -0.61 at -1 and 0 lag. The lower SLP corresponds with frequent NW-cloud bands and higher Vaal River flow. Conversely, in summers with higher SLP over the east Atlantic NW-cloud bands are diminished and potential evaporation losses accumulate. For example in the 1980s drought, potential evaporation > $270 \mathrm{~mm} / \mathrm{month}$ was observed. Although river discharge is less influenced by the (Pacific) Southern Oscillation $(r=+0.28$ at 0 lag), potential evaporation in the Vaal basin shows significant covariance $(r=-0.61)$. This is because dry conditions cause vegetation wilting and increased potential evaporation a month later. The lag-correlation graphs, using summer-only values over the 1979-2014 period, are given in Fig. 8b.

\section{SUMMARY}

This study has shown that summers with high flow in the Vaal River coincide with ocean-atmosphere interaction in the east Atlantic. The research covered: (i) inter-annual influences on summer discharge by correlation with climate fields 1979-2014, (ii) atmosphere and ocean composites of 14 peak flow months, and (iii) a flood on 23-26 January 2010 and its regional forcing.
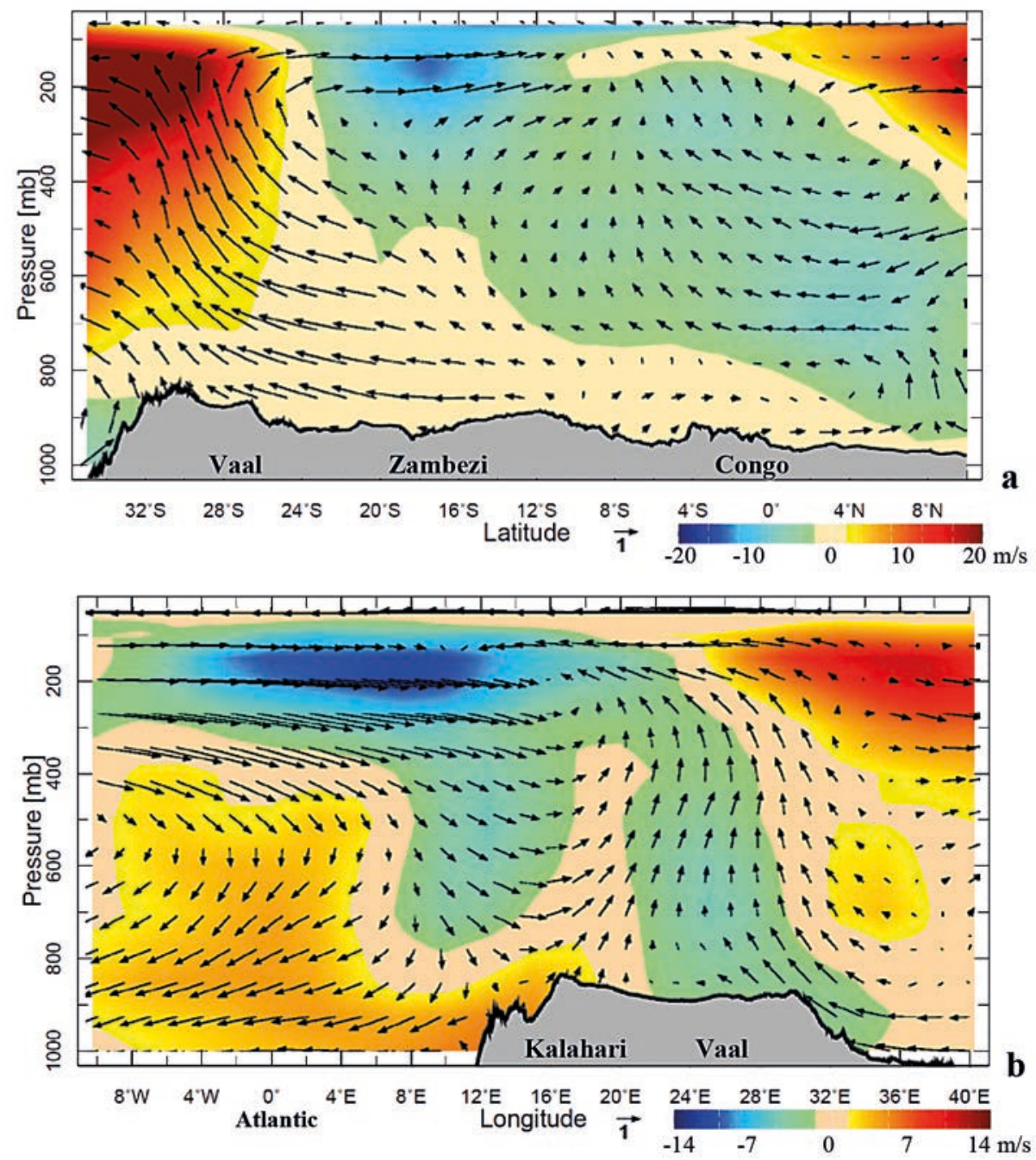

Figure 7

Vertical sections of atmospheric circulation 23-26 January 2010: (a) meridional overturning vectors, zonal wind shaded, averaged 22-30E. (b) Same but zonal overturning vectors and meridional winds shaded, averaged 17-27S. Topography profile given with regional names. 

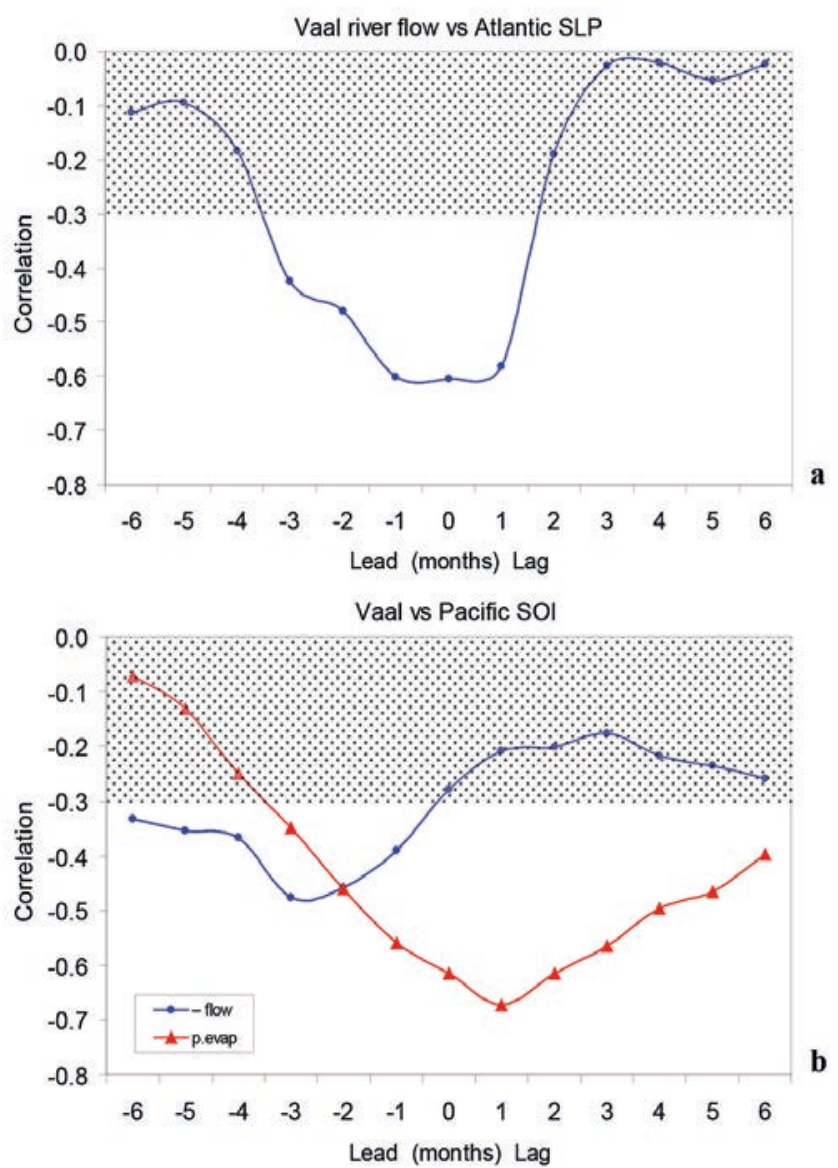

Figure 8

Lag-correlation plot of detrended Dec-Feb Vaal River flow and (a) Atlantic SLP (4OW-20E, 30S-35N), and (b) Pacific Southern Oscillation Index 1979-2014. 90\% confidence is <-0.3. Values are inverted for flow in (b); correlations $<90 \%$ confidence are stipled.

Inter-annual links were established with low pressure over the east Atlantic and a reversed zonal overturning ocean circulation that spreads warm water toward Angola. A key mode of summer rainfall variability is expressed through NW-cloud bands (cf. Figs 3a, 5b) that connect the east Atlantic with South Africa. The Vaal flood in January $2010\left(2801 \mathrm{~m}^{3} / \mathrm{s}\right)$ followed 2 months behind the Congo River and its low-salinity discharge plume. Unusually warm waters in the east Atlantic and surplus transpiration in the western Zambezi, combined with a NW-trough to feed moist air toward the Vaal River catchment. The composite analysis of 14 high-flow months confirms a climatic pattern similar to this flood event.

Further work could elaborate on the connection between NW-cloud bands and the equatorial Atlantic Ocean circulation, and Pacific Southern Oscillation influence on potential evaporation. If seasonal hydrology forecasts can be improved, then risks of drought and flood could be more efficiently mitigated.

\section{ACKNOWLEDGEMENTS}

The author thanks South Africa's Department of Water and Sanitation for hydrological data distributed by Internet. Satellite and model interpolated data were analysed from the Climate Explorer, IRI Climate Library and NASA Giovanni websites.

\section{REFERENCES}

ALEMAW BF and CHAOKA TR (2006) The 1950-1998 warm ENSO events and regional implications to river flow variability in Southern Africa. Water SA 32 459-463.

AMARASEKERA KN, LEE RF, WILLIAMS ER and ELTAHIR EAB (1997) ENSO and the natural variability in the flow of tropical rivers. J. Hydrol. 200 24-39. http://dx.doi.org/10.1016/ S0022-1694(96)03340-9

CAMBERLIN P, JANICOT S and POCCARD I (2001) Seasonality and atmospheric dynamics of the teleconnection between African rainfall and tropical sea surface temperature: Atlantic vs. ENSO. Int. J. Climatol. 21 973-1005. http://dx.doi.org/10.1002/joc.673

CARTON JA and HUANG B (1994) Warm events in the tropical Atlantic. J. Phys. Oceanogr. 24 888-903. http://dx.doi. org/10.1175/1520-0485(1994)024<0888:WEITTA >2.0.CO;2

CHANG P, JI L and LI H (1997) A decadal climate variation in the tropical Atlantic Ocean from thermodynamic air-sea interactions. Nature 385 516-518. http://dx.doi.org/10.1038/385516a0

CHANG P, SARAVANAN P, JI L and HEGERL GC (2000) The effect of local sea surface temperatures on atmospheric circulation over the tropical Atlantic sector. J. Clim. 13 2195-2216. http://dx.doi.org/10.1175/1520-0442(2000)013<2195:TEOLSS >2 .0.CO;2

CHASSIGNET EP, HURLBURT HE, METZGER EJ, SMEDSTAD OM, CUMMINGS JA, HALLIWELL GR, BLECK R, BARAILLE R, WALLCRAFT AJ, LOZANO C, TOLMAN HL and co-authors (2009) US GODAE: Global ocean prediction with the Hybrid coordinate ocean model (Hycom). Oceanography 22 64-75. http:// dx.doi.org/10.5670/oceanog.2009.39

DETTINGER MD and DIAZ HF (2000) Global characteristics of stream flow seasonality and variability. J. Hydrometeorol. 1289 310. http://dx.doi.org/10.1175/1525-7541(2000)001<0289:GCOSFS $>2.0 . \mathrm{CO} ; 2$

ENFIELD DB and MAYER DA (1997) Tropical Atlantic sea surface temperature variability and its relation to El Niño-Southern Oscillation. J. Geophys. Res. 102 929-945. http://dx.doi. org/10.1029/96JC03296

EUROPEAN SATELLITE AGENCY (2015) EUMETSAT. URL: www. eumetsat.int/website (Accessed January 2015).

GLAD PA (2010) Meteorological and hydrological conditions leading to severe regional drought in Malawi. MSc thesis, Department of Geoscience, University of Oslo. 129 pp.

HIRST AC and HASTENRATH S (1983a) Diagnostics of hydrometeorological anomalies in the Congo basin. Q. J. R. Meteorol. Soc. 109 881-892. http://dx.doi.org/10.1002/qj.49710946213

HIRST AC and HASTENRATH S (1983b) Atmosphere-ocean mechanisms of climate anomalies in the Angola-tropical Atlantic sector. J. Phys. Oceanogr. 13 1146-1157. http://dx.doi. org/10.1175/1520-0485(1983)013<1146:AOMOCA>2.0.CO;2

HUETE A, DIDAN K, MIURA T, RODRIGUEZ EP, GAO X and FERREIRA LG (2002) Overview of the radiometric and biophysical performance of the MODIS vegetation indices. Remote Sens. Environ. 83 195-213. http://dx.doi.org/10.1016/ S0034-4257(02)00096-2

JOYCE RJ, JANOWIAK JE, ARKIN PA and XIE PP (2004) CMORPH: A method that produces global precipitation estimates from passive microwave and infrared data at high spatial and temporal resolution. J. Hydrometeorol. 5 487-503. http:// dx.doi.org/10.1175/1525-7541(2004)005<0487:CAMTPG >2.0 .CO;2

JURY MR and ENGERT S (1999) Teleconnections modulating inter-annual climate variability over northern Namibia. Int. J. Climatol. 19 1459-1475. http://dx.doi.org/10.1002/(SICI)10970088(19991115)19:13<1459::AID-JOC397>3.0.CO;2-A

JURY MR, MULENGA H and RAUTENBACH H (2000) Tropical Atlantic variability and Indo-Pacific ENSO: Statistical analysis and numerical simulation. Glob. Atmos. Ocean Syst. 7 107-124.

JURY MR and MPETA EJ (2009) African climate variability in the satellite era. Theor. Appl. Climatol. doi10.1007/s00704-009-0106-0. http://dx.doi.org/10.1007/s00704-009-0106-0 
JURY MR (2010) Flood-producing cloud bands over the Kalahari Desert. Theor. Appl. Climatol. 102 367-378. http://dx.doi. org/10.1007/s00704-010-0259-x

KALNAY E, KANAMITSU M, KISTLER R, COLLINS W, DEAVEN D, GANDIN L, IREDELL M, SAHA A, WHITE G, WOOLLEN J and co-authors (1996) The NCEP/NCAR 40-Year Reanalysis Project. Bull. Am. Meteorol. Soc. 77 437--471. http://dx.doi. org/10.1175/1520-0477(1996)077<0437:tnyrp>2.0.co;2

KEENLYSIDE NS and LATIF M (2007) Understanding equatorial Atlantic interannual variability. J. Clim. 20 131-142. http://dx.doi. org/10.1175/JCLI3992.1

KRUGER AC (1999) The influence of the decadal-scale variability of summer rainfall on the impact of El Nino and La Nina events in South Africa. Int. J. Climatol. 19 59-68. http://dx.doi.org/10.1002/ (SICI)1097-0088(199901)19:1<59::AID-JOC347>3.0.CO;2-B

LATIF M and GROTZNER A (2000) The equatorial Atlantic oscillation and its response to ENSO. Clim. Dyn. 16 213-218. http://dx.doi. org/10.1007/s003820050014

MATSOUKAS C, BENAS N, HATZIANASTASIOU N, PAVLAKIS KG, KANAKIDOU M and VARDAVAS I (2011) Potential evaporation trends over land between 1983-2008: driven by radiative fluxes or vapour-pressure deficit? Atmos. Chem. Phys. 11 7601-7616. http://dx.doi.org/10.5194/acp-11-7601-2011

ORASECOM (ORANGE-SENQU RIVER BASIN COMMISSION) Orange-Senqu River Awareness Kit. URL: www.orangesenqurak. com (Accessed January 2015)

PHILANDER SGH (1986) Unusual conditions in the tropical Atlantic Ocean in 1984. Nature 322 236-238. http://dx.doi. org/10.1038/322236a0

POTTER C, ZHANG P, KLOSTER S, GENOVESE V, SHEKHAR S and KUMAR V (2004) Understanding controls on historical river discharge in the world's largest drainage basins. Earth Interact. 8 1-21. http://dx.doi.org/10.1175/1087-3562(2004)008<0001:UCOHR $\mathrm{D}>2.0 . \mathrm{CO} ; 2$

REYNOLDS RW, SMITH TM, LIU C, CHELTON DB, CASEY KS and SCHLAX MG (2007) Daily high-resolution blended analyses for sea surface temperature. J. Clim. 20 5473-5496. http://dx.doi. org/10.1175/2007JCLI1824.1

RIENECKER MM, SUAREZ MJ, GELARO R, TODLING R, BACMEISTER J, LIU E, BOSILOVICH MG, SCHUBERT SD, TAKACS L, KIM G-K and co-authors (2011) MERRA: NASA's Modern-Era Retrospective Analysis for Research and Applications.
J. Clim. 24 3624-3648. http://dx.doi.org/10.1175/JCLI-D-11-00015.1 ROUAULT M, FLORENCHIE P, FAUCHEREAU N and REASON CJC (2003) South East Atlantic warm events and southern African rainfall. Geophys. Res. Lett. 30 http://dx.doi.org/10.1029/2002GL014840 SARAVANAN R and CHANG P (2000) Interaction between tropical Atlantic variability and El Niño-Southern Oscillation. J. Clim. 13 2177-2194. http://dx.doi.org/10.1175/1520-0442(2000)013<2177:IBT AVA $>2.0 . C O ; 2$

SCHNEIDER U, BECKER A, FINGER P, MEYER-CHRISTOFFER A, ZIESE M and RUDOLF B (2013) GPCC's new land surface precipitation climatology based on quality-controlled in-situ data and its role in quantifying the global water cycle. Theor. Appl. Climatol. http://dx.doi.org/10.1007/s00704-013-0860-x

SERVAIN J, PICAULT J and MERLE J (1982) Evidence of remote forcing in the equatorial Atlantic Ocean. J. Phys. Oceanogr. 12 457-463. http:// dx.doi.org/10.1175/1520-0485(1982)012<0457:EORFIT>2.0.CO;2

SUTTON, RT, JEWSON SP and ROWELL DP (2000) The elements of climate variability in the tropical Atlantic region. J. Clim. $133261-$ 3284. http://dx.doi.org/10.1175/1520-0442(2000)013<3261:TEOCV I $>2.0 . \mathrm{CO} ; 2$

TADROSS MA, HEWITSON BC and USMAN MT (2005) The interannual variability of the onset of the maize growing season over South Africa and Zimbabwe. J. Clim. 18 3356-3372. http://dx.doi. org/10.1175/JCLI3423.1

TALJAARD JJ (1985) Cut-off lows in the South African region. South African Weather Bureau Technical Paper 14. South African Weather Bureau, Pretoria. 153 pp.

TAPLEY BD, BETTADPUR S, RIES JC, THOMPSON PF and WATKINS MM (2004) GRACE measurements of mass variability in the earth system. Science 305 http://dx.doi.org/10.1126/science.1099192

TODD MC and WASHINGTON R (2004) Climate variability in central equatorial Africa: influence from the Atlantic sector. Geophys. Res. Lett. 31 23201-23205.

TORRENCE C and COMPO GP (1998) A practical guide to Wavelet Analysis. Bull. Am. Meteorol. Soc. 79 61-78. http://dx.doi. org/10.1175/1520-0477(1998)079<0061:APGTWA>2.0.CO;2

TUCKER CJ, PINZON JE, BROWN ME, SLAYBACK DA, PAK EW, MAHONEY R, VERMOTE EF and EL SALEOUS N (2005) An extended AVHRR $8 \mathrm{~km}$ NDVI dataset compatible with MODIS and SPOT vegetation data. Int. J. Remote Sens. 26 4485-4498. http:// dx.doi.org/10.1080/01431160500168686 


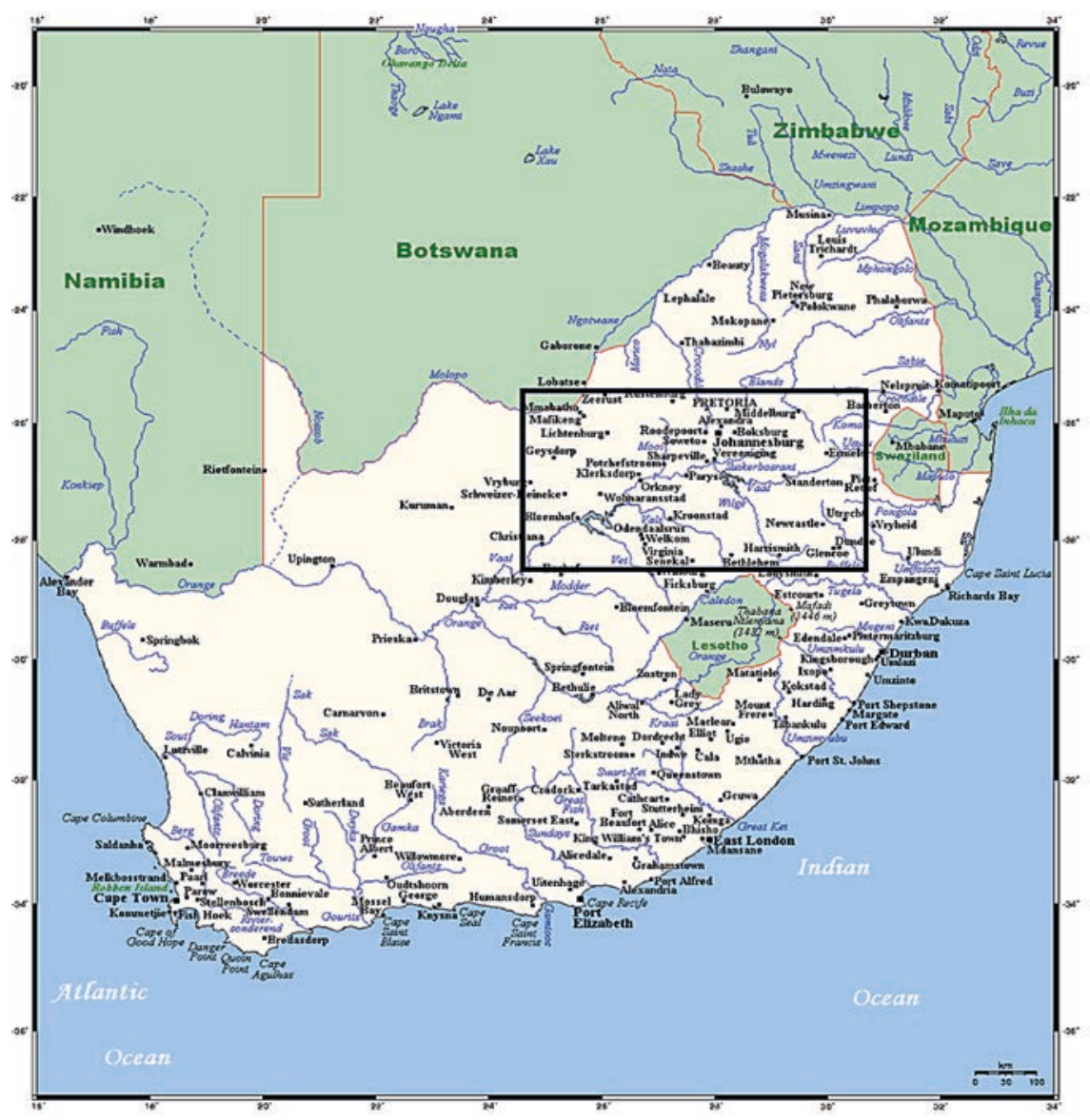

Figure A1

National map of South Africa with catchment boundary given in Fig 1a,c. 